\title{
女子大学生のインフルェンザ・感冒罹患，特に 寮生と通学生との比較について \\ Modes of Spread of Influenza and Common Cold among Boarders and Externs of a Women's College
}

\author{
京都府立医科大学铸生学教室 \\ 永田久紀・額田褛 \\ 奈良女子大学家政学部 \\ 清 水増子・北 村 君 \\ Hisanori Nagata, Akira Nukata \\ Department of Hygiene, Kyoto Prefectural Medical University \\ Masuko Shimizu, Kimi Kitamura \\ Department of Domestic Science, Nara Women's College
}

われわれの日常生活あるいは作業能率に及ぼす影響と いう点からみると, いわゆる感冒はその症状は軽度であ るが重要な疾病であり，昭和 31 年11月に扮てなわれた国 民健康調查の結果 ${ }^{1)}$ でも急性悬咽頭炎の月間䍜患率は第 1 位を占めている。また，一昨年よりインフルェンザは 全国的大流行をみているが2-1)，非流行期に执いてイン フルエンザと症状のうえで多くの類似点をもつ感冒がぞ の程度に発生しているかを知つておくことは, 疫学上か らも防疫対策上加も必要であるょうに思われる。

一方, 学校保健の立場少ら反ると, 寮生活には, 伝染 性疾患の流行の点加ち, 末た寮生に:及济す身体的心 理的影響の面からも問題になるととが多い。心理的影響 も無視できないと思われる感冒様症状の寮生間における 発生状況を知るととは寮生活の健康管理に必要と思われ る。

以上の見地方らわれわれは奈良女子大学家政学部学生 を対象として, 昭和 32 年 11 月初旬から昭和 33 年 6 月中旬 に至る期間に，インフルェンザならびに感冒の罹患状況 を特に寮生と通学生との比較に重点を置いて調査したの でことに報告する。

\section{調查方法}

奈良女子大学家政学部学生を対象として毎週調查票を 配布し，その週に抢いて i）発熱，ii）悪感，iii）全身 倦急，iv）頭痛，v）四肢痛 - 腰痛，vi）咳嗽，vii）哂 頭痛，viii） 鼻汗鼻閉などの症状があつたか否かを記入 せしめた。

調查人員は第 1 表に示すと抢りで, 調查は昭和 32 年 11. 月初旬から昭和 33 年 6 月中旬侄る間, 冬休及・春休み. を除く18週にわたつて抗となった。

\section{調查成績ならびに考察}

\section{1) 罹患率}

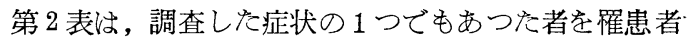
とみなし, 寮生通学生別, 学年別に各週の罹患率を求め た結果である。ただし, 全身倦总, 頭痛, 四肢痛・腰痛 の症状のうち，1つだけを訴えた者は罹患者から除外し た。インフルエンサザ流行期には高い罹患率を示し, 非流 行期には罹患率の低いことは当然と思われるので, 以下 11 12月, $1 \sim 2$ 月, $4 \sim 6$ 月の 3 時期に分つて検討し てみるととにする。

\section{a) 11〜12月の罹患率}

との期間はいわりるアジアインフルエンザの流行期で あつたため, 罹患率は相当に高い。察生と通学生との罹 患率を比較すると,この期間中の罹患率は寮生が $61.1 \%$ ， 通学生が59.1\%とほとんぞ同一であるが, 流行の経過は かなり異なつている。すなわち, 寮生では流行の山が比 較的に明膫で, 高学年・低学年ともに11月初旬に罹患率 


\begin{tabular}{|c|c|c|c|c|c|c|c|}
\hline$\frac{2}{5} \frac{10}{2}$ & $\sim$ & ని & $\mathscr{m}$ & จิ & $\exists$ & $\vec{m}$ & 6 \\
\hline$\sum_{i}^{\infty}$ & $\sim$ & ని & ది & ฉి & $\exists$ & $\vec{m}$ & $\widehat{0}$ \\
\hline 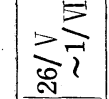 & $\wedge$ & ని & $\mathscr{m}$ & ฉి & 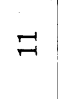 & $\overrightarrow{~ ल े ~}$ & 8 \\
\hline 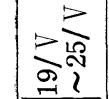 & $\infty$ & $\hat{\mathrm{N}}$ & 鬲 & $\vec{N}$ & $\stackrel{9}{\sim}$ & $\vec{m}$ & 8 \\
\hline 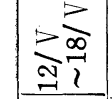 & $\infty$ & $\hat{\mathrm{N}}$ & 兽 & $\vec{N}$ & $\stackrel{9}{\sim}$ & ले & 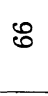 \\
\hline$\underset{i n}{i=7}$ & $\infty$ & $\stackrel{\infty}{N}$ & 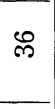 & $\vec{N}$ & 오 & ले & $\hat{0}$ \\
\hline$\underset{\substack{\infty \\
i}}{+}$ & $\exists$ & శి & $F$ & $\mathscr{\sim}$ & 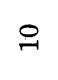 & $\mathscr{N}$ & $\hat{0}$ \\
\hline$\underset{\substack{\text { Ni } \\
\text { तi }}}{Z}$ & $\Rightarrow$ & సે & $\stackrel{\infty}{\infty}$ & $\vec{N}$ & $\sigma$ & లి & 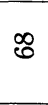 \\
\hline 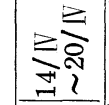 & 욱 & న & 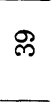 & $\vec{N}$ & 0 & లి & 8 \\
\hline 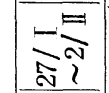 & 10 & $\stackrel{10}{-1}$ & จิ & ని & -1 & 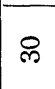 & is \\
\hline $\begin{array}{l}\overline{-} \\
\overline{\bar{O}} \\
\bar{\partial} \hat{N}\end{array}$ & 10 & $\stackrel{10}{\rightarrow}$ & ৪ి & 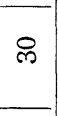 & N & ले & กิ \\
\hline$\underset{-\overrightarrow{9}}{-\overrightarrow{9}}$ & 0 & $\stackrel{\infty}{N}$ & ले & $\vec{m}$ & $n$ & $\infty$ & $\mathfrak{N}$ \\
\hline 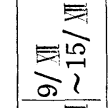 & $r$ & $\stackrel{\infty}{N}$ & 狦 & $\vec{m}$ & 0 & 아 & 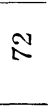 \\
\hline $\begin{array}{c}\sum \\
\sum i \\
i\end{array}$ & 0 & $\stackrel{\mathscr{N}}{\mathrm{N}}$ & ले & $\vec{m}$ & $\infty$ & F & $\underset{\Sigma}{ }$ \\
\hline$\underset{2}{E 2}$ & $\nabla$ & 总 & 网 & $\vec{m}$ & 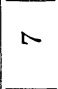 & 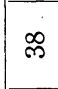 & $\widehat{0}$ \\
\hline$\underset{\substack{\infty \\
\stackrel{N}{\gtrless}}}{\stackrel{F}{i}}$ & 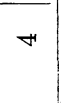 & 18 & ন্ & $\vec{m}$ & 0 & ஸे & 8 \\
\hline$\underset{=}{\stackrel{E}{2}}$ & 10 & $\vec{N}$ & নి & $\tilde{m}$ & 0 & 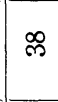 & $\widehat{0}$ \\
\hline 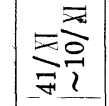 & 10 & $\stackrel{\mathscr{N}}{*}$ & $\vec{m}$ & $\stackrel{m}{m}$ & $\infty$ & ஐ & 茫 \\
\hline & $\begin{array}{l}4 \\
4 \\
m \\
0\end{array}$ & $\begin{array}{l}\text { सा } \\
\text { से } \\
-1 \\
\text { N }\end{array}$ & 葯 & $\begin{array}{l}4 \\
4 \\
6 \\
\pi \\
\pi^{4}\end{array}$ & $\begin{array}{l}4 \\
\text { 过 } \\
-1 \\
\text { s }\end{array}$ & 相 & \multirow[t]{2}{*}{$\begin{array}{l}\text { 株 } \\
\text { 㯺 }\end{array}$} \\
\hline & 排 & & 4 & 澴 & 朴 & & \\
\hline
\end{tabular}

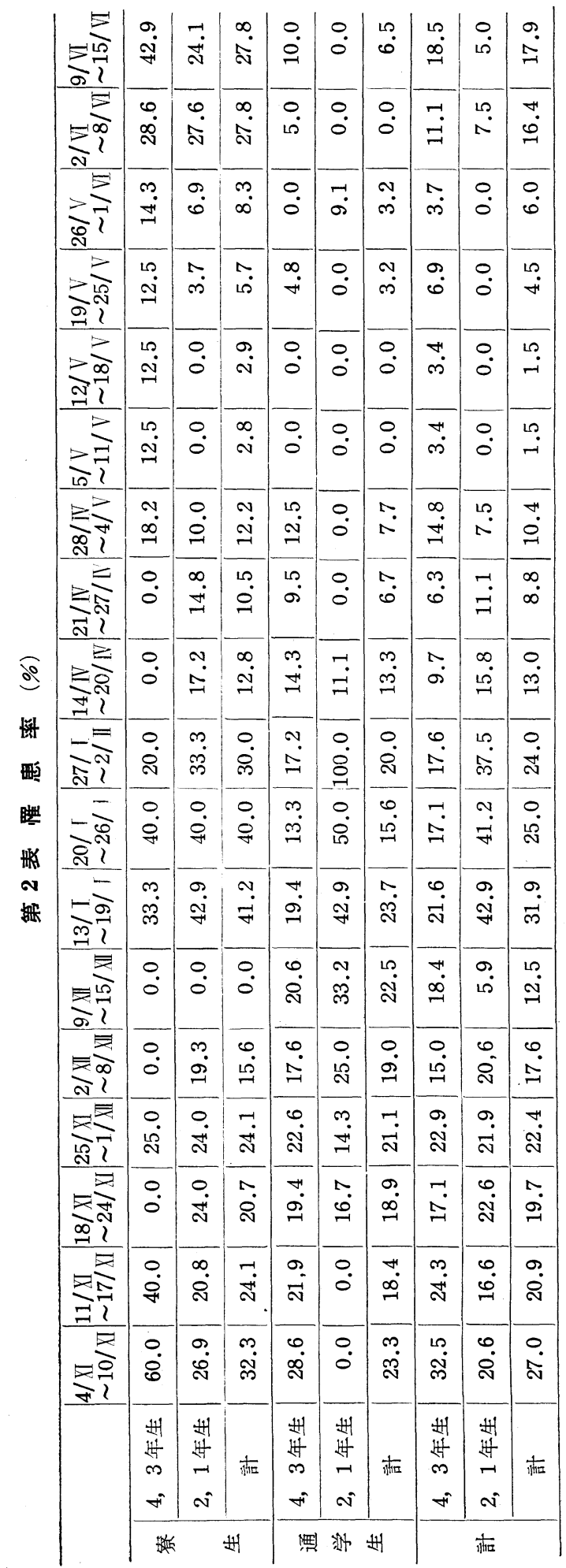


が最高で, その後次第に減少しているが, 通学生では流 行の山がはつきり認められず，高学年では11月から12月 にかけて毎週厓とんご同じ罪患率を示し, 低学年では逆 に11月下旬から 12 月にかけて罹患者が多くなつている。 寮生通学生別, 学年別, 調查週別の罹患率を角変換して要 因分析した結果は第 3 表に示すように寮生と通学生, 高 学年と低学年で流行の経過が異なるととを示している。

このようにインフルエンザの流行が小集団どとに異な つた経過をとるのはその伝染様式の相違によるものと思 われる。

第 3 表

\begin{tabular}{|c|c|c|c|}
\hline 要 因 & SS & $\mathrm{DF}$ & MS \\
\hline W（週別） & 493.0 & 5 & 98.6 \\
\hline $\mathrm{G}$ (寮生通学生別) & 9.5 & 1 & 9.5 \\
\hline Y（学年別） & 43.0 & 1 & 43.0 \\
\hline $\mathrm{W} \times \mathrm{G}$ & 2279.3 & 5 & $455.9 *$ \\
\hline $\mathrm{W} \times \mathrm{Y}$ & 1488.8 & 5 & $297.8^{*}$ \\
\hline $\mathrm{G} \times \mathrm{Y}$ & 252.8 & 1 & 252.8 \\
\hline $\mathrm{W} \times \mathrm{G} \times \mathrm{Y}$ & 227.4 & 5 & 45.5 \\
\hline total & 4793.8 & 23 & \\
\hline
\end{tabular}

$* \mathrm{p}<0.05$

b) $\quad 1 \sim 2$ 月の罹患率

この時期にはインフルェンザの流行は既に終つていた が，罹患率は11〜12月ょり高く，特に学校の始まつた最 初の週は $31.9 \%$ 高率を示している。

寮生と通学生との比較では, 特に高学年において寮生 の罹患率の方が高い傾向が認められるが, その差は有意 でない。いずれにしても非流行時にも拘らず，厳寒期に 感冒またはインフルェンザ様症状を訴える者がこのょう

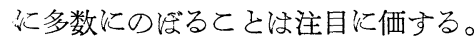

c) 4 〜 6 月の罹患率

4 月 14 日〜 5 月 4 日の間では, 罹患率は寮生・通学生と 毛に每週10\%内外を数えた。寮生通学生別, 学年別, 週
別の罹患率に有意の差は認められなかつたが, 学校の始 まつた最初の週の罹患率は他の週より高いようである。 この傾向は特に寮生の新入生に著しく, 第 1 週には 29.4 \%がなんらかの症状を 訴えている。新入生は種々の感

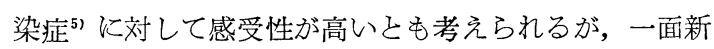
入生にとつて寮生活がかなりの心理的身体的負担になる とともみのがせない。

5 月 5 日〜 6 月 1 日の間は寮生・通学生ともに䍜患率 はきわめて低かつたが, 6 月 2 日以後罹患率が再び上昇 している。6月 2 日以後の罹患の状況をみて第一に気が つくことは罹患者が主に寮生にみられることで, 寮生と 通学生との罹患率の差を Fisher の直接確率計算法化よ つて検定すると， 6 月 2 日からの 1 週間に抢いても ( $=0.006), 6$ 月 9 日からの 1 週間に沶いても $(P=0.02)$ 有意である。要するに寮生活では呼吸器伝染病の感染の 機会が多く，容易に伝播する傾向が認められる。

\section{2) 自覚症状}

第 4 表は,自覚症状に基づいて疾病の程度を i) 全身局 所症状を認め発熱を类なつた場合（発熱のほかに悪感, 全身倦怠, 頭痛, 四肢痛・腰痛なざの全身症状 1 つ以上 之咳嗽, 咽頭痛, 鼻汗鼻閉などの局所症状 1 つ以上を訴 えた場合)，ii）全身局所症状を認めるが発熱を伴なわな かつた場合（発熱を除く全身症状 $2 つ$ 以上局所症状 1 つ以上学訴えた場合), iii) 局所症状を主訴とするが軽 度の全身症状のある場合 (発熱学除く全身症状 1 つと局 所症状 2 つ以上を訴えた場合), iv) 局所症状の及学:訴え た場合の 4 段階に分類し, $11 \sim 12$ 月, $1 \sim 2$ 月, $4 \sim 5$ 月, 6 月の 4 時期別, 寮生通学生別にその頻度を調查し た結果である。

インフルエンザ流行期の11〜12月では寮生通学生とも に過半数が局所症状とともに全身症状を示し, 発熱を伴 なつた者も相当数を数元た。1〜2月に扔いては罪患率 涼高いが症状の軽い場合が多く, 全身症状, 特に発熱を 伴なつた場合は比較的に少数にすぎなかつた。寮生通学

第 4 表 自覚症状による疿病程度の分類

\begin{tabular}{|c|c|c|c|c|c|c|c|c|}
\hline & \multicolumn{2}{|c|}{$11 \sim 12$ 月 } & \multicolumn{2}{|c|}{$1 \sim 2$ 月 } & \multicolumn{2}{|c|}{$4 \sim 5$ 月 } & \multicolumn{2}{|c|}{6 月 } \\
\hline & 寮生 & 通学生 & 寮生 & 通学生 & 寮生 & 通学生 & 寮生 & 通学生 \\
\hline 全身局所症状を認め発熱を伴なつた場合 & 10 & 10 & 2 & 2 & 1 & 2 & 2 & 0 \\
\hline 全身局所症状を認めるが発熱を伴なわなかつた場合 & 4 & 12 & 2 & 5 & 6 & 0 & 7 & 1 \\
\hline 局所症状を主訴とするが軽度の全身症状を伴なら場合 & 5 & 2 & 6 & 4 & 3 & 5 & 1 & 1 \\
\hline 局所症状のみを訴えた場合 & 5 & 6 & 5 & 4 & 3 & 2 & 2 & 1 \\
\hline 計 & 24 & 30 & 15 & 15 & 13 & 9 & 12 & 3 \\
\hline
\end{tabular}


生別の比較では寮生の方に全身症状を伴なう場合がいく ぶん少ないようであるが相違は顕著ではない。4 5 月 に掠いては寮生では過半数が全身症状を伴なつたが, 通 学生では全身症状を伴なつた場合は少なかつた。しかし 寮生・通学生ともに発熱を伴なつた者はきわめて少数て あつた。6月では罹患者は主に寮生で，発熱者は比較的 に少なかつたが大多数がなんらかの全身症状を訴え，特 に全身倦急と鼻汁鼻閉定 訴える者が多いととが目立つ た。この時期に打ける疾患は, 寮生間に主に発生した点 と症状の特殊性からみて, 一種の流行性疾患であつたょ うに思われる。

\section{3) 䍜㭧回数}

第 5 表は全調查期間を通じて調查をおてないえた57名 について罹患回数を調査した結果である。1 回も罹患し なかつた者は寮生で18.5\%, 通学生で13.0\%にすぎず, 寮生では $51.9 \%$, 通学生では $39.1 \%$ が 2 回以上罹患して

第 5 表 䍜患回数

\begin{tabular}{|c|c|c|c|c|c|c|}
\hline & \multicolumn{2}{|c|}{ 寮 生 } & \multicolumn{2}{|c|}{ 通学生 } & \multicolumn{2}{|c|}{$\begin{array}{l}4 \text { 月以降尞生から } \\
\text { 通学生に变つた者 }\end{array}$} \\
\hline & 例数 & $\%$ & 例数 & $\%$ & 例数 & $\%$ \\
\hline 0 回 & 5 & 18.5 & 3 & 13.0 & 1 & 14.3 \\
\hline 1 回 & 8 & 29.6 & 11 & 47.8 & 1 & 14.3 \\
\hline 2 回 & 9 & 33.4 & 3 & 13.0 & 4 & 57.1 \\
\hline 3 回 & 5 & 18.5 & 6 & 26.1 & 1 & 14.3 \\
\hline 計 & 27 & & 23 & & 7 & \\
\hline
\end{tabular}

第 6 表

\begin{tabular}{|c|c|c|c|c|}
\hline & \multicolumn{2}{|c|}{ 寮 生 } & \multicolumn{2}{|c|}{ 通学生 } \\
\hline & 実数 & 期待数 & 実数 & 期待数 \\
\hline 1 回む罹患しなかつた者 & 5 & 3.7 & 3 & 3.4 \\
\hline $\begin{array}{l}3 \text { 時期中 } 1 \text { 時期にのみ羅 } \\
\text { 患した者 }\end{array}$ & 9 & 11.1 & 11 & 10.4 \\
\hline 2 時期に罹患した者 & 9 & 9.6 & 8 & 8.0 \\
\hline 3 時期に罹患した者 & 4 & 2.6 & 1 & 1.2 \\
\hline
\end{tabular}

いる。

一部の者が特によく罹患する傾向があるか否かをみる ために，調査期間を11〜12月, $1 \sim 2$ 月, $4 \sim 6$ 月の 3 時 期に分ち，この 3 時期のいずれの時期にも罹患した者, そのうち 2 時期に罹患した者， 1 時期に罹患した者， 1 回も罹患しなかつた者の実数と期待数を，調査期間中に 寮生正ら通学生に変つた 7 名を除〈50名について, 寮生 通学生別に比較してみると第 6 表のごとく通学生では実 数と期待数とはきわめてょく一致したが，寮生では 3 時 期とも罹患した者, 1 回も罹患しなかつた者の実数が期 待数安やや上回つた。すなわち寮生では一部の者が頻 回に罹患する傾向が多少 みられるょうである。な拉， 期待数はこの対象についての 各時期における 罹患率=

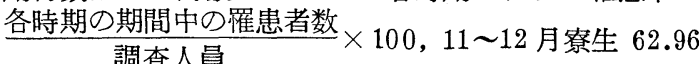
$\%$, 通学生 $65.22 \%, 1 \sim 2$ 月寮生 $37.04 \%$, 通学生 $47.83 \% ， 4 \sim 6$ 月寮生 $40.74 \%$, 通学生 $17.39 \%$ を基 礎としこれょり算出した。

\section{4) 疶病の持綂期間}

第 7 表は時期別, 寮生通学生別に疾病の持続期間を示 したものである。

全体的にみて疾病の $65.3 \%$ 週間以内に軽快してい るが, 寮生と通学生の疾病持続期間を比較するとインフ ルェンザの流行期であつた11〜12月を除いて，1～2月 においても $4 \sim 6$ 月に括いても寮生では通学生に比べて 疾病持続期間の長い者の割合が多いことが目立つ。1〜 2 月, $4 \sim 6$ 月の疾病数の合計について及ると疾病が 2 週間以上にわたつたものは寮生では $50.0 \%$ 占めるが, 通学生では18.5\%にすぎず，2つの百分率の間には有意 の差が認められる $\left(x^{2}=5.61 \quad \mathrm{n}=1 \quad \mathrm{P}<0.05\right) 。$

とのように寮生の感冒持続期間は長びく傾向が認めら れるが，罹患した寮生に対する適切な養護が望まれる。

\section{総括}

奈良女子大学家政学部学生約 70 名を対象として, 昭和 32 年11月初旬方ら昭和 33 年 6 月中旬に至る期間に，イン

第 7 表 疾病の持続期間

\begin{tabular}{|c|c|c|c|c|c|c|c|c|c|c|c|c|}
\hline \multirow{3}{*}{$\begin{array}{l}\text { 症状 } \\
\text { 持続期間 }\end{array}$} & \multicolumn{4}{|c|}{$11 \sim 12$ 月 } & \multicolumn{4}{|c|}{$1 \sim 2$ 月 } & \multicolumn{4}{|c|}{$4 \sim 6$ 月 } \\
\hline & \multicolumn{2}{|c|}{ 寮 生 } & \multicolumn{2}{|c|}{ 通学生 } & \multicolumn{2}{|c|}{ 寮 生 } & \multicolumn{2}{|c|}{ 通学生 } & \multicolumn{2}{|c|}{ 寮 生 } & \multicolumn{2}{|c|}{ 通学生 } \\
\hline & 例数 & $\%$ & 例数 & $\%$ & 例数 & $\%$ & 例数 & $\%$ & 例数 & $\%$ & 例数 & $\%$ \\
\hline 1 週間以内 & 18 & 75.0 & 19 & 63.3 & 7 & 46.7 & 12 & 80.0 & 13 & 52.0 & 10 & 83.3 \\
\hline 2 週間以上 & 6 & 25.0 & 11 & 36.7 & 8 & 53.3 & 3 & 20.0 & 12 & 48.0 & 2 & 16.7 \\
\hline 計 & 24 & & 30 & & 15 & & 15 & & 25 & & 12 & \\
\hline
\end{tabular}


フルエンザならびに感冒の罹患状況を寮生・通学生の比 較に重点を置いて調査し, 次の結果を得た。

1）調查の期間中11〜12月はアジアインフルェンザの 流行期であつたが, 寮生では流行の山が比較的に明瞭で あつたのに反し, 通学生では流行の山がはつきり認めら れなかつた。また，5月下旬から 6 月にかけて寮生間に 一種の伝染性疾患の流行が認められた。要するに寮生活 では呼吸器伝染病の感染の機会が多く, 容易に伝播する ようである。

2）休暇あけの最初の週にはいろいろな症状を訴える 者が比較的に多いが，乙の傾向は特に寮生の新入生に著 しい。

3）寮生では一部の者が頻回に罹患する傾向が多少認 められたが，通学生ではそのような傾向はまつたく認め られなかつた。

4）寮生では通学生に比べて感冒の持続期間が長びく
傾向が認められた。

終りに調查に協力された奈良女子大学家政学部の学生 諸姉に感謝する。

\section{参考文献}

1) 厚生省官房統計調查部編 : 国民健康調查, 昭和31 年 11 月.

2）松田心一 : 厚生の指標, 5 巻, 1 号, 13頁, 昭和 33年 1 月。

3）前田道明 : 日本医事新報, No. 1748, p. 43, 昭 和 32 年 10 月.

4) 松田心一・石橋敏男: 厚生の指標, 5 巻, 5 号, 31 頁, 昭和 33 年 5 月。

5）福見秀雄 : 臨牀と研究, 35巻, 813頁, 昭和 33 年 7 月。

（受付：1958 年 8 月 26 日） 